\title{
Article
}

\section{Developing systems to control food adulteration}

Manning, Louise and Soon, Jan Mei

Available at http://clok.uclan.ac.uk/14025/

Manning, Louise and Soon, Jan Mei ORCID: 0000-0003-0488-1434 (2014)

Developing systems to control food adulteration. Food Policy, 49 (1). pp. 23-

32. ISSN 0306-9192

It is advisable to refer to the publisher's version if you intend to cite from the work.

http://dx.doi.org/10.1016/j.foodpol.2014.06.005

For more information about UCLan's research in this area go to

http://www.uclan.ac.uk/researchgroups/ and search for < name of research Group>.

For information about Research generally at UCLan please go to

http://www.uclan.ac.uk/research/

All outputs in CLoK are protected by Intellectual Property Rights law, including Copyright law. Copyright, IPR and Moral Rights for the works on this site are retained by the individual authors and/or other copyright owners. Terms and conditions for use of this material are defined in the policies page.

\section{CLoK}

Central Lancashire online Knowledge www.clok.uclan.ac.uk

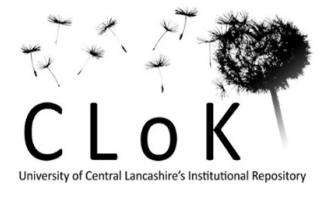




\section{Elsevier Editorial System(tm) for Food Policy Manuscript Draft}

Manuscript Number: FOODPOLICY-D-13-00249R2

Title: Developing systems to control food adulteration

Article Type: Full Length Article

Keywords: food fraud; adulteration; economically motivated adulteration; crime; criminally; standards

Corresponding Author: Dr. Louise Manning, PhD

Corresponding Author's Institution:

First Author: Louise Manning, Ph.D

Order of Authors: Louise Manning, Ph.D

Abstract: The objective of this study is to explore the current strategies available to monitor and detect the economically and criminally motivated adulteration of food, identifying their strengths and weaknesses and recommend new approaches and policies to strengthen future capabilities to counter adulteration in a globalized food environment. Many techniques are used to detect the presence of adulterants. However, this approach relies on the adulterant, or means of substitution, being "known" and an analytical method being available. Further techniques verify provenance claims made about a food product e.g. breed, variety etc. as well as the original geographic location of food production. These consider wholeness, or not, of a food item and so do not need to necessarily identify the actual adulterant just whether the food is complete. The conceptual framework developed in this research focuses on the process of predicting, reacting and detecting economically and criminally motivated food adulteration 
Highlights

Discussion of economic and criminally motivated food adulteration

Reviews challenges that exist in the supply chain using food supply examples

Reviews techniques for determining food adulteration product wholeness

Conceptual framework developed focuses on the process of predicting, reacting and detecting economically and criminally food adulteration 
Developing systems to control food adulteration

Louise Manning ${ }^{1}$ and Jan Mei Soon ${ }^{2}$

${ }^{1}$ Royal Agricultural University, Stroud Road, Cirencester, Gloucestershire UK

${ }^{2}$ Faculty of Agro Based Industry,

Universiti Malaysia Kelantan, Kelantan, Malaysia

Corresponding author ${ }^{1}$

Keywords: economically, criminally, motivated, adulteration, substitution 
Ms. Ref. No.: FOODPOLICY-D-13-00249R1

Title: Developing systems to control food adulteration

Food Policy

Reviewers' comments:

Reviewer \#1: The paper has been greatly improved with this revision and I do recommend publication after some minor revisions suggested below.

Response: Thank you

General comments:

Abstract \& highlights: change "economically and criminally food adulteration" to "economically and criminally motivated food adulteration"

Response: Thank you for the suggestion. We have added „motivated" into the text (Line 19, pg. 1).

Whole paper: Suggest replacing the term "wholeness" with integrity throughout the entire paper. The concept of food integrity is in principal the same as wholeness, but the former is a more established term in food policy.

Response: Thank you for the comment this has been changed Line 31, pg.2; and as required later in the paper

Page 3: I suggest toning down "It was determined that global anti-counterfeiting activities for the food and drug sector are projected to be worth $\$ 79.3$ billion by 2014 (Li 2013)." to "It has been suggested that..." All numbers in literature on the economic cost of EMA (although I haven't reviewed this particular reference) are based on anecdotal evidence and not science, so this should be toned down. Response: The word determined has been toned down to suggested (line 58, pg. 3).

Page 3: A better definition for the specific type of adulteration (EMA) discussed in this paper should be used and referenced (see below refs). It is helpful to use the term "Economically Motivated Adulteration" instead of just "adulteration" since the later in some countries like the USA has a different meaning in regulations.

Moore, Jeffrey C., John Spink, and Markus Lipp. "Development and application of a database of food ingredient fraud and economically motivated adulteration from 1980 to 2010." Journal of food science 77, no. 4 (2012): R118-R126.

Everstine, Karen, John Spink, and Shaun Kennedy. "Economically motivated adulteration (EMA) of food: common characteristics of EMA incidents." Journal of Food Protection $\circledast 76$, no. 4 (2013): 723735.

Spink, John, and Douglas C. Moyer. "Defining the public health threat of food fraud." Journal of food science 76.9 (2011): R157-R163.

Response: Term adulteration has been amended to food adulteration and specific focus on economically and criminally motivated adulteration. This has been refocused throughout the paper. A definition of ENA has been inserted. (Spink and Moyer, 2011:32). Line 75; pg 3

Page 12: The following phrase is no longer accurate: "a comprehensive database about known problematic ingredients and detection methods does not currently exist" and should be replaced by "a comprehensive database about known problematic ingredients and detection methods did not exist until 2012 when the USP Food Fraud Database was established"

Response: The word determined has been toned down to suggested (line 238, pg. 10).

Page 14: Replace "Moore et al. (2012) reviewed and collected over 1000 records of food frauds and analytical methods in the US Pharmacopeia Food Chemicals Codex" with "Moore et al. (2012) reviewed and collected over 1000 records of food frauds and analytical methods published in the USP 
Food Fraud Database"

Response: Changed to USP Food Fraud Database (line 296, pg. 12).

Page 20: References and discussion on FDA's Vulnerability Assessment Software and Carver + Shock tool is not accurate. These tools are not designed to assess vulnerabilities in a food supply for EMA issues, but rather, intentional food defense issues. Would suggest re-framing this point to an argument that tools are needed to assess the likelihood or probability of food fraud/adulteration occurring and that current tools like FDA's Vulnerability Assessment Software and Carver + Shock are not suitable for this purpose. You can reference US FDA's recent proposed rule on Intentional Adulteration part IV-F on EMA.

Response: The authors have re-framed the CARVER + Shock and VAS Tools as focused on predicting attacks (from a food defense point of view) (lines 462-471, pg. 18-19).

Figure 1 is very difficult to understand. I suggest revising this figure or explaining more clearly in the text. For example the box "earliest time before food and feed is adulterated..." does not make sense to me as it appears to fall before the beginning of the food chain.

Response: The authors have placed the text box "earliest time befor food and feed is adulterated..." to the start of the food chain (on the right) and explained in detail the reactive and predictive systems from lines 541-564 (pg. 21-22).

Reviewer \#2: I would recommend that this paper undergo another revision to reduce the history and provide more support for the theories that make up the framework. The figure demonstrating the framework was the strength of this paper and should become a greater focus. As it currently read, the history and legislation regarding food adulteration is the focus. The author's point can be made that there is a long history and much current activity in this field, and there is movement toward enhanced legislation, but there are many issues that cannot be solved with this approach. A framework to enhance investigation is required.

Response: History element has been reduced - Line 72 onwards - pg. 3

Wording changed to reflect comments on framework

For further assistance, please visit our customer support site at http://help.elsevier.com/app/answers/list/p/7923 Here you can search for solutions on a range of topics, find answers to frequently asked questions and learn more about EES via interactive tutorials. You will also find our 24/7 support contact details should you need any further assistance from one of our customer support representatives. 
9 The objective of this study is to explore the current strategies available to monitor and detect the economically and criminally motivated adulteration of food, identifying their strengths and weaknesses and recommend new approaches and policies to strengthen future capabilities to counter adulteration in a globalized food environment. There are many techniques used to detect the presence of adulterants, however this approach relies on the adulterant or means of substitution being "known" and no food item can ever be declared truly free of adulteration on that basis. Further techniques will verify the provenance claims made about a food product e.g. breed, variety etc.as well as techniques to identify original geographic location of food production. These consider wholeness, or not, of a food item and do not need to necessarily identify the actual adulterant. The conceptual framework developed in this research focuses on the process of predicting, detecting and reacting to economically and criminally motivated food adulteration.

\section{Introduction}

Food adulteration is an age-old problem especially where there is a challenge between the physical availability of, and the market demand for, a food item. This is further impacted if there is juxtaposition between the cost of production, say of meat or meat-based products, and the price the supply chain customer (at a supplier/customer interface) or the end user is prepared to pay for the product. The objective of this study is to explore the current strategies available to monitor and 
detect the economically and criminally motivated adulteration of food, identifying their strengths and weaknesses and recommend new approaches and policies to strengthen future capabilities to counter adulteration in a globalized food environment. This paper begins by discussing the context of economically and criminally motivated food adulteration and then reviews the evolving techniques used to detect the presence of known adulterants, to identify product integrity, or otherwise, of foodstuffs as well as techniques to identify original geographic location of food production. A conceptual framework is developed and then its application discussed.

Whilst there is much focus in the literature, quite rightly, on the definitions of food safety and the agents that render food unsafe there is less emphasis on the nature of product integrity or wholeness. Adapting the term for "wholeness" in the Collins Dictionary (2013), the term product integrity can be described as the inherent quality of containing all the component parts necessary to form a total; i.e. completeness. Product integrity in this context could be further described as meeting the agreed specification that has been laid down in terms of expressing the total completeness of the item that is "undiminished, without removal of part" (Adapted from Sykes 1976). By inference, failure to meet this specification indicates, to the limits of the testing methods, that a food may have been contaminated, have undergone substitution or has been adulterated. This approach does not require the party undertaking the testing to identify the specific contaminant rather just to identify that the specification of integrity for that commodity has not been met. As analytical techniques become more accurate the depth of the specification of "what described integrity" for a given food item will change and develop as discussed later in this paper. Defra (2013) states that food standards legislation sets out specific requirements for the labelling, composition and, in some cases, safety parameters for specific high value foodstuffs that are potentially at risk of being misleadingly substituted with lower quality alternatives. This is as opposed to food safety that addresses food that is injurious to health (Food Safety Act, 1990). In their Food Law Enforcement Plan 2010/2011, the London Borough of Tower Hamlets (2010: 3) states that "standards inspections are seen as a second priority" to that of food hygiene and as a 
result, far less sampling for composition, labelling, claims, allergens, etc. is done. It is food standards that this research particularly focuses on and dependent on the adulterant or substitution concerned this may, or may not, also be a food safety problem.

\section{Adulteration in a globalized food environment}

It has been suggested that global anti-counterfeiting activities for the food and drug sector are projected to be worth $\$ 79.3$ billion by 2014 ( $\mathrm{Li}, 2013$ ). In order to outline the context of this statistic this section compares and contrasts a number of food adulteration and fraud cases in both developed and developing countries.

\section{United Kingdom / European Union}

Scally (2013) argues that the lengthening of food supply chains, accompanied by the increased industrialization of the food business, has had a profound effect on the food culture of developed countries. Indeed he proposes that modern food processing has created the opportunity to practice consumer fraud on a truly massive and international scale. The fraud can be undertaken in one country and then the actual impact can be in countries far removed from the perpetrators especially so as the globalization and consolidation of food procurement increases further (Manning et al. 2005). Therefore, it is possible to contaminate food in a country where regulatory and market controls are limited and cause major human health consequences and economic disruption in another where on the surface such controls appear stringent.

Food adulteration can be described as the actions that are taken to add or adjust a food item or composite food product by the use of extraneous, substandard, or inferior ingredients. Food fraud may be carried out intentionally for economic gain, with the associated actions undertaken to avoid detection by regulatory bodies or consumers (Grundy et al. 2012). Economically motivated adulteration (EMA) has been described as "The fraudulent, intentional substitution or addition of a substance in a product for the purpose of increasing the apparent value of the product or reducing the cost of its production, i.e. for economic gain." (Spink and Moyer, 2011:32). Economically and 
criminally motivated food adulteration is nothing new. Accum (1820) identified that at that time that there had been a range of successful prosecutions in the United Kingdom (UK) for counterfeiting and adulteration of tea, coffee, bread, beer, and pepper. These were both a concern with regard to food safety as well as being of a food standards issue. Accum determined that adulteration was a widespread practice involving a number of food items and also exposed the culinary fraud practices in London and detailed how bakers cut their flour with alum, chalk, plaster and sawdust to make them heavier. Other fraud cases at the time involved brewers adding bitter substances such as strychnine to beer and the use of lead, copper or mercury salts to make bright coloured sweets and jellies.

In April 2013, the European Commission reported on testing that had been carried out in the wake of concern over meat product adulteration (EC, 2013). The results indicated that, for the products tested for the presence of horse DNA $(n=4144), 4.7 \%$ revealed positive traces of horse DNA. For the products tested for the presence of phenylbutazone $(n=3115) 0.51 \%$ showed positive traces of the drug. In addition, Member States (MS) reported tests performed by food business operators (producers, processors and distributors; $\mathrm{n}=7951$ ) for the presence of horse DNA; $1.38 \%$ had horse DNA present. The UK Food Standards Agency (FSA) also identified products labelled as "Halal" that contained pork (FSA, 2013). Beef adulteration in Europe highlights not only the continued problem with food fraud, but also the potential for unwitting cross-contamination at "micro levels" during standard meat processing activities where multi species meats are processed/prepared in the same vicinity and using the same equipment. This means that products (that would have previously been declared as "free from" or "whole" in terms of being suitable for a certain cultural or religious group) as analytical methods develop, and as limits of detection reduce, may not indeed be found to meet that specification. The discrepancy may be at the level of parts per million (ppm) or parts per billion (ppb) but this may not be acceptable to consumers e.g. in terms of pesticide residues or the presence of DNA from other animal species. This creates a current and future challenge that the 
industry will need to address both in practical terms in trying to reduce these minimal levels further and also with meeting cultural expectations.

\section{United States}

There is much work from the United States (US) that focuses on food fraud and food adulteration (Everstine et al., 2013; Spink and Moyer 2013; Moore et al., 2012; Spink and Moyer 2011) As an example of the types of incidents identified, a 2012 report on food fraud in US restaurants and retail outlets (Warner et al. 2012) concluded that 58\% of the eighty-one retail outlets sampled, sold mislabeled fish with small markets having a higher incidence of fraud (40\%) than national chain grocery stores $(12 \%)$. Furthermore, all of the sushi bars $(n=16)$ tested sold mislabeled fish and $94 \%$ of the "white tuna" tested was not tuna at all. As previously discussed this type of adulteration could be caused for a variety of reasons e.g. by accidental means due to a failure in either process or supply chain controls or as a result of premeditated criminal activity.

\section{India}

One of the key problems in India is the intentional contamination of food with look-alike substances. The look-alike substances were substituted in items like incidents of brick powder in red chillies, lead chromate in turmeric and vegetable oil contamination with milk fat (Shukla et al., 2014). A 2011 survey in India of adulteration in liquid milk found that $68 \%$ of the randomly collected samples tested $(\mathrm{n}=1791)$ were non-conforming (FSSAI, 2011). In some states the level of non-compliance was $100 \%$. The non-conformity of samples in rural areas was found to be $31 \%$ of which $81 \%$ were loose (unpacked) samples. In urban areas $69 \%$ of samples were non-conforming (67\% loose samples). Detergent was found (8\%); skimmed milk powder (45\%) and glucose (27\%) of the samples. In seven Indian states all samples taken were found to be impure. This demonstrates the level of milk adulteration being practiced in India. The biggest dairy food fraud incident to date using melamine, that also had serious implications for public health, was in China. 


\section{China}

132 Melamine is rich in nitrogen and contains 67\% nitrogen per mass unit (Merck Research

133 Laboratories, 2001). Due to the high nitrogen content, melamine was added, as an adulterant, to

134 food commodities such as milk and wheat gluten to "increase" the perceived protein content and

135 avoided detection as milk was tested for protein using a method based on total nitrogen content

136 (Schoder, 2010). In 2006 dairy production in China faced rising feed prices so $40 \%$ of dairy farmers

137 were losing money and a further $30 \%$ were just breaking (Jia et al. 2012). Whilst dairy processing

138 firms were demanding increased milk supply as a result of consumer demand some farmers were

139 culling their herds due to the lack of profitability. This aggravated the already tight milk supply in

140 China. In early 2007 the new shortage of milk supplies threatened to push up the price of milk

141 products (Jia et al. 2012). The use of protein powders in milk was prohibited; such powders could

142 be sourced from ground animalsee parts, soy and other food sources. Later, manufacturers of plastics

143 started seeing a demand for melamine, but there was no connection made between the two

144 supposedly separate incidents.

145 An increased incidence of kidney stones and renal failure among infants was identified in China in

146 December 2007 and Sanlu Customer Service Department received consumer complaints about their

147 products (Xiaojing, 2011). [Concurrently there was a pet food recall for melamine contamination of

148 pet food ingredients in the US due to contamination of wheat gluten.] In June 2008 complaints

149 appeared on the State Council Administration for quality, supervision, inspection and quarantine

150 (AQSIQ) website. Official inspectors then assessed the commodities produced by Sanlu, and once

151 adulteration was identified all batches produced up to December 2007 were recalled. In August

1522008 melamine was reported as being detected in 15 out of 16 lots tested, but a recall was not

153 instigated until the government ordered Sanlu to stop production and distribution of product in

154 September 2008 (Xiaojing, 2011). In that month it was announced that 59 infants had developed

155 kidney stones and one child had died. In September 2008, the WHO (2008) identified that there had 

been 6240 cases of kidney stones in China with three deaths. The WHO reported that at least 22 dairy manufacturers across China were found to have melamine in some of their products (the levels varied between $0.09 \mathrm{mg} / \mathrm{kg}$ and $2.560 \mathrm{mg} / \mathrm{kg}$ ). Gossner et. al. (2009) determined that kidney and urinary tract effects, including kidney stones, affected about 300,000 Chinese infants and young children, with six reported deaths.

Further forty-seven countries received the melamine-contaminated products and sixty-eight countries banned or recalled foods suspected of containing melamine (Gossner et. al. 2009 citing Bhalla et al. 2009). Food fraud, as in this example, can occur in commercial circumstances when there is an issue with the bridging of the supply of and demand for a food commodity. Substitution can arise as a result of an illegal activity to fill the "supply gap" or to meet the cost structure at the stages of the food supply chain where there is a reticence or inability for increasing operational costs to be passed through to the end consumer.

As a result of this incident, the Chinese government was forced to react to ensure the safety and quality of Chinese food products through the implementation of food safety laws, increasing penalties for illegal practice and by instituting a system of risk evaluation that included monitoring 500,000 companies (Ramzy, 2009). It should be stressed that within the diverse and complex global food supply chains there are constraints to addressing food safety, food standards and corruption at local, national and international levels. Furthermore, maintaining confidence in a food supply chain in order to ensure continued economic growth is not an issue localized only to China. The Chinese case study merely serves as an example of the challenges presented with regard to control of food adulteration. As Accum (1820) identified such activities were evident in a developing UK food culture and the examples given in this paper highlight they continue to be prevalent today.

Although the use of melamine in China as a food adulterant gained attention from 2007, adulteration continues to be a problem with further arrests and prosecutions in China in 2011 (Coghlan, 2011). Melamine contamination has also been identified in milk purchased in twelve out of fourteen samples from markets in Iran (Hassani et al. 2013). These examples highlight the 
continued use of this adulterant and why routine product testing for melamine is so critical to verify continued product compliance and to seek to prevent contaminated materials from being used in the food supply chain and/or consumed. However, often food fraud is undertaken with the full knowledge and understanding of the systems of surveillance and control and the analytical tests that are currently used at borders and within countries. The constituents used for emerging and reemerging food fraud are targeted on this basis either for the reason that they are not currently routinely tested for in surveillance and verification testing and food import control protocols or that the adulterant used will pass existing analytical tests without identification.

\section{Economically motivated adulteration}

Contamination maybe accidental or unintentional particularly when farmers or processors are unaware of that a set of circumstances they put in place could potentially lead to contamination of food. However, when food adulteration becomes intentional, this is when criminal and economically driven factors can come into play. Practices of deliberate contamination of food and drug ingredients may be widespread and also avoid detection in poorly regulated markets where surveillance is minimal. For example, in China there are over 500,000 food processing businesses and slim profit margins drove some owners to cut cost by substituting food with cheaper ingredients (Zach et al. 2012). Substitution may include diluting infant formula (Xiu and Klein 2010), using diethylene glycol as a substitute for glycerin (FDA 2008), using illegal red dyes in duck eggs (Du and Sun, 2007) and relabeling of seafood products (D'Amico et al. 2014). If deliberate contamination is motivated by financial gain, the practices are likely to be concealed and if undiscovered, to recur (Brown and Brown 2010).

Due to their high market value, meat products are often targets for species substitution and adulteration (Cawthorn et al. 2013). A study undertaken in South Africa on processed meat products $(n=139)$ identified that $68 \%$ of samples contained species that were not declared on the product labelling, with the incidence being highest in sausages, burger patties and deli meats i.e. 
processed foods rather than carcass meats. Soya and gluten were identified as undeclared plant proteins in a large number of samples (28\%), whilst pork (37\%) and chicken (23\%) were the most commonly detected animal species. Cawthorn et al. (2013) also reported that unconventional species such as donkey, goat and water buffalo were discovered as species that had been substituted for another origin. They conclude that mislabeling of processed meats is commonplace in South Africa and this not only violates food labeling regulations, but also poses economic, religious, ethical and health impacts.

In the EU, syndicates took advantage of the price-support structure of the European Common Agricultural Policy for financial gain. For example, butter produced within the EU receives a subsidy payment because of lower market prices when exported to a „third“e (non-EU country). Then the same consignment of butter was re-labeled as produce of the third country before being reimported back into the EU. The re-labeled butter was subjected to income tax at a lower rate than the original subsidy paid on the export. Hence, by re-labeling the origin of the butter, syndicates were able to make illegal profit of up to $£ 30,000$ per $25,000 \mathrm{~kg}$ consignment of butter (Kelly et al. 2005). Spink and Moyer (2011) identified seven types of food fraud (Table 1) namely adulteration, counterfeit product, diversion of products outside of intended markets, over-run, simulation, tampering and theft. Each type of food fraud generates different potential levels of monetary gains and the degree of gain is dependent on how well the ,fraud ${ }^{\text {ee }}$ has been carried out and if detection of the crime occurs. For example, when white sturgeon caviar is substituted with beluga caviar, consumers pay five times more than they should for the product (Cohen 1997).

\section{Take in Table1}

Everstine et al. (2013) argue that EMA incidents reveal voids in quality assurance testing methodologies that can be exploited for intentional harm. Indeed gaps in traceability, quality assurance programmes or interfaces between different certification schemes will be exploited where 
they occur by some individuals for economic benefit. Everstine et al. (2013) suggest in their study that 137 documented and distinct EMA incidents had been identified. The food product categories ranged from protein products to spices and sweeteners. Moore et al. (2012) determine that whilst food ingredient fraud and EMA are emerging risks, a comprehensive database about known problematic ingredients and detection methods did not exist until 2012 when the USP Food Fraud Database was established. The proliferation of potential adulterants demonstrates that any "screening based" approach needs to be diverse and wide reaching in its scope. Product testing can be costly and introduce time delays, especially at border inspection points, in a food supply chain that is both highly price sensitive and continuously driving towards a just in time approach to minimize the costs of holding/storing stock. Organizations will vary in the extent to which they use/undertake risk-benefit evaluations such as hazard analysis critical control point (HACCP) for food safety and a threat or vulnerability analysis critical control point (TACCP or VACCP) assessment to determine the risk of vulnerability to fraud or bioterrorism incidents. These approaches identify the process controls and product testing that is deemed necessary to minimize risk to the organization, their customers and the final consumer (FDA, 2013a).

The WTO/SPS agreement (WHO, 1997) introduced the term "appropriate level of sanitary or phytosanitary protection" (ALOP) i.e. the level of protection deemed appropriate by a Country or Member State establishing a Sanitary and/or Phytosanitary (SPS) measure to protect human, animal or plant life or health within its borders. By setting a food safety objective (FSO), competent authorities can determine a risk-based limit that should be achieved operationally within the food chain, while providing flexibility for different production, manufacturing, distribution, marketing, and preparation approaches (CAC, 2007). Furthermore, a performance objective (PO) can be determined i.e. the maximum frequency and/or concentration of a food safety hazard in a food at a specified step in the food chain before the time of consumption that provides or contributes to an FSO or ALOP (CAC, 2011). However, the FSO and PO can only be determined if the food safety hazard or contaminant is "known" and there has been a scientific risk-based determination of the 
acceptable level of the hazard within a food. In the case of "unknown unknowns" this risk assessment approach falls down. By its nature EMA is often within this category as the food adulteration or substitution has the potential to cause harm if ingested. In instances of food fraud only the fraudsters know how the food has been manipulated and to what extent the substitution is a labelling or a food safety issue and also how it was introduced into the food supply chain. However, the fraudsters may neither care nor have the knowledge, the expertise, or the resources to determine if the substitution or manipulation undertaken poses any acute or chronic risk to consumers. Hence, the public health risks of adulterated food are often unknown until it is too late (Moore et al. 2012). Spink and Moyer (2011) also state that the public health risks from adulterated food are more risky than traditional food safety threats because the contaminants are often unconventional. There are a non-exhaustive number of potential EMA contaminants and a risk-based approach requires a high degree of knowledge or expert opinion in order to appropriately quantify the level of risk. However such expert knowledge will be lacking or non-existent with some EMA, since this is the very reason why they were chosen in the first place. Economic influences will create a situation where alternative ingredients or materials are sought by supply chain partners that are "cheaper" than standard ingredients and can go largely undetected in the current product monitoring and verification regimes. Food analysis is often at the accuracy level of ppm or ppb and this has led to the development of techniques often described as food forensics. This particular field will need to develop strongly in order to meet the global challenges of food fraud.

\section{Food forensics}

The use of nonspecific analytical tests in routine product testing is one of the risk factor for the incidence of EMA (Everstine et al. 2013). The wide range of substances that can be used in food fraud coupled with the impossibility to analyse them all, make conventional testing unsuitable for

284 food adulteration problems. In order to cover the widest range of adulterants usually requires 285 sophisticated analytical equipment such as mass spectrometry (Di Stefano et al. 2012). It could be 
argued that the melamine adulteration incident occurred because the analytical method used to determine protein content was non-specific and thus by adulteration a "false" reading could be obtained. Kjedahl or combustion (Dumas) method measures the protein content based on total nitrogen content and do not differentiate between protein nitrogen or non-protein nitrogen (Moore et al. 2010). As a result of this, individuals took advantage of their ,misused ${ }^{\text {ee }}$ food chemistry knowledge to enhance the determined level of the protein content of milk, knowing that the tests were of non-specific nitrogen tests.

The US Pharmacopeia (2012) advocates a proactive approach i.e. the testing of food ingredients for authenticity rather than testing for the absence of specific adulterants (Moore et al. 2012). Moore et al. (2012) reviewed and collected over 1000 records of food frauds and analytical methods published in the USP Food Fraud Database. The database is useful to identify trends and developments and provide stakeholders with information on methods to detect food frauds. According to Primrose et al. (2010), determining the description of food in terms of its total composition, processing or origin is challenging, but there are a number of techniques that have been successful in verifying the authenticity of food. This includes stable isotope analysis, genomics and proteomics.

In 2005 a code of practice was developed for the control of basmati rice sold in the UK (BRC, 2005). If a product is identified as "basmati rice" then the non-basmati rice element cannot exceed $7 \%$ of the packed product. It is difficult to differentiate between basmati and non-basmati grains based on visual test or physicochemical tests but research has been undertaken to identify adulteration of basmati rice as low as $1 \%$ in a sample through the use of tests that focus on varietyspecific allele profiles (Archak et al., 2007). In the Uonuma district of Japan, high quality rice has been bred with a specific genetic marker. The genetically distinctive rice sold under licence to Uonuma farmers will prevent inferior rice from being falsely sold under the districtes name (Ravilious 2006; Kitaoka et al. 2010). Kitaoka et al. (2010) suggested that the method would be able to identify food from a particular location. This is also of importance when considering 
provenance i.e. the country of origin or geographic indication claims associated with food products.

313 Grundy et al. (2012) citing Kelly (2003) and Kelly and Bateman (2009) argue that analysis of stable

314 isotopes in foods can reveal EMA such as addition of cheap sugar syrups to extend honey and

315 maple syrup; watering down of wine; preparation of fruit juice described as "freshly squeezed"

316 from concentrate; verification that chicken has been "corn-fed"; determination of whether ethanol

317 and vinegar and flavorings are natural or synthetic; and differentiation between organic and

318 conventional farming methods. All food and drink contains hydrogen and oxygen elements that

319 originate from where the animal or plant received water from the local water sources. Both

320 hydrogen and oxygen have heavy and light isotopes and the ratio of light to heavy isotopes is a

321 unique marker for climate and geographical area. Carbon isotopes can be used to differentiate plant

322 groups. Kelly et al. (2005) suggested that as a first approximation, natural abundance measurements

323 would provide information on plant ,type ${ }^{e e}$ or diet (carbon and nitrogen isotope ratios), and

324 geographical origin (hydrogen, oxygen, sulphur and strontium isotope ratios). Therefore local

agricultural practices and animal diet can affect ${ }^{15} \mathrm{~N} /{ }^{14} \mathrm{~N}$ and ${ }^{13} \mathrm{C} /{ }^{12} \mathrm{C}$ ratios respectively. Indeed, the

geographic origin (rearing location) of animals used in meat production can be determined (Heaton

et al. 2007). Beef reared in the US ( $\mathrm{n}=23)$ and Brazil $(\mathrm{n}=10)$ was found to be isotopically different

from northern European beef $(n=35)$, mainly because of contrasting proportion of plants with $\mathrm{C} 3$ and C4 photosynthetic pathways in the cattle diets (Schmidt et al., 2004). Isotopic maps of Europe are being developed so that prized, regional products such as Champagne, Gloucestershire cheese and Scottish salmon can be confidently matched with their places of origin (Ravilious 2006). More recent research has utilized stable isotope techniques in reviewing egg authentication schemes (Rock, 2012); geographic origin of beef (Liu et al.2013); and authenticity and quality of food of animal origin (Vinci et al. 2012).

One of the drawbacks of using purely chemical analytical techniques in seeking to detect food adulteration is that as previously described there is a finite number of analytes that have been determined and thus methods developed to determine their presence/absence at a defined limit of 
detection. Utilising spectral or chromatographic techniques can identify patterns that can be compared with standards for unadulterated foods and anomalies to be identified even if the exact constituent that is causing the variability is unknown. However in some instances such as the adulteration of foods with Sudan 1 targeted analysis is required. This is true of spectral methods such as near infra-red spectroscopy (IR) and nuclear magnetic resonance (NMR). Fingerprinting refers to the spectrum or the image generated by certain analytical tools and the types of fingerprinting can be classified into three categories (Table 2): spectral fingerprinting and chromatographic fingerprinting and electrophoresis fingerprinting (Zhang et al. 2011). The use of such fingerprinting technology has seen the detection of source, materials and components in food such wines (Casale et al. 2010), cereals (Valeria et al. 2005) and fish protein (Hubert et al. 2008; Serge et al. 2007). Table 3 shows the application of the different kinds of food fingerprinting in food detection analysis.

\section{Take in Tables 2 and 3}

Additionally, DNA barcoding is a powerful method in determining morphologically unidentifiable fish or meat product samples as long as the DNA is preserved in the sample (Maralit et al. 2013). It is effective in determining the origin of raw materials and the detection of adulteration e.g. by mixing products from different taxonomy such as rice and ginseng (Galimberti et al. 2013: Niu et al. 2011). The primary goal of DNA barcoding is to assembly reference libraries of code sequences for known food species in order to develop reliable, molecular tools for identification (Hubert et al. 2008). DNA tests, sequencing and databases can be developed for all meat types and will make it possible to trace the meat to the individual animal type, breed and locality of origin along with isotope analysis. In the UK, such tests are not part of routine surveillance and DNA sampling can cost $£ 200$ to $£ 500$ per food sample (Thomson 2013). This prohibits its use as an on-line quality assurance and process test method. Having outlined the role of both product verification activities what is the value of process verification in addressing EMA? 


\section{Process vs. Product verification}

366

Food standards assessment activities focus on both product and process verification. Process verification through the assessment of documentation, certification and traceability data is less costly than destructive product inspection and testing, but such verification rests on the ability to assess valid evidence in terms of documentation, records, labelling and evidence of certification. Fraud prevention and anti-counterfeiting tools can be used to track and trace movements of food products through the supply chain. Machine readable devices (barcodes, QR codes, data matrix) allow a number of checks to be enhanced and the electronic data can be shared (Dabbene, Gay and Tortia, 2013). Information shared between the different partners in the supply chain can decrease potential food frauds as the number of traceable units are documented and monitored for suspicious transactions.

It is important that the traceable resource unit (TRU) or distinct batch must be uniquely identified (Moe, 1998 citing Kim et al., 1995). Over time, product traceability methods have been developed that are based on the ability to identify products uniquely as a result of physical marking on the product or its package or by the use of associated records (Moe, 1998). Moe argued that a traceability system could be split into two elements firstly the "route" of the product and the sequence of steps that it passes through so it is traceable through manufacturing, distribution and the retail system and the "scope" of the traceability in terms of the inherent nature of the product. This has been built on in more recent years with the introduction of "mass-balance" traceability checks for a TRU. Mass balance traceability is an essential pre-requisite within the food supply chain for assuring extrinsic quality. This process assures that identity preserved products are indeed what they purport to be. Mass balance checks routinely determine an organization ${ }^{\text {ee }}$ ability to identify, locate and "contain" a specific TRU of ingredient, part-processed or final product. The capacity to do this is critical in the event of a product withdrawal or a full product recall from the supply chain. It is also important to determine that the volume of product being sold as a specific 
TRU where provenance, production method (organic, free range or Fairtrade) or cultural claim e.g.

391 slaughter method (halal) and whether this could have indeed been produced in that quantity from 392 the resources that were claimed to have originally been made available. This is largely an 393 electronic record and/or a paper-based exercise especially if the "stock" has left the production 394 premises. This is problematical when the reliability and authenticity of data is subverted in the 395 event of food fraud. Therefore process verification alone is of limited value in determining or 396 identifying EMA.

397 The UK Independent Farming Regulation Task Force in their 2011 report (IFRTF, 2011) 398 recommended that industry engage "fully with Government and third party assurance bodies to

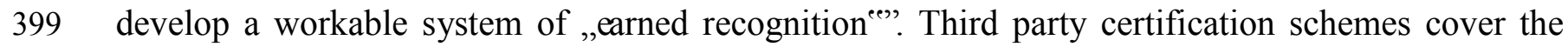
400 certification of the management of the production, storage and handling of the products at a discrete 401 point in the supply chain and are not, in the main, product specific certification schemes, although 402 the generic product types are identified in the scope of certification for each organization. This 403 means that in their current form, third party certification schemes have limited impact on the control 404 of product verification only in as much as there was compliance with supply chain specifications on 405 the day of the audit. This form of verification is more about the process and generic controls. 406 Furthermore, verification of process and product through review and auditing provides the auditor 407 with a range of evidence, or audit observations, which can be both qualitative e.g. interviews, 408 observations and records or quantitative based on measurement and test. However, it is important to 409 consider whether third party certification of organizations against management system standards 410 can either guarantee increased compliance with statutory food standards product requirements or 411 that such certification activities will address covert fraudulent behaviour which by its nature 412 involves the falsification of product, labelling and/or documentation at one point or several points in 413 the supply chain. If the records or labelling verified was: 
- the processes being undertaken do not include re-confirmation of the validity of such documentation and labelling with the product batch delivered, and

- there is no analytical or organoleptic evidence available of fraudulent activity when the product is being inspected,

then the fraud will not be readily identified or prevented by this type of third party certification. Indeed, fraudulent behaviour, by its criminal nature, is unlikely to occur during a timetabled third party certification audit. The Elliott Review Interim Report (HM Government, 2013) suggests that the food industry moves to reducing the number of announced certification audits undertaken and replacing them with unannounced audits. However unless the certification standards contain specific elements that will be assessed with regard to EMA and food fraud this will have limited benefit. The effectiveness of the certification activity depends upon the cooperation of the organization being audited, which in the event of criminal activity may well mean the auditor will face limited disclosure. It should also be considered that if an auditor discovers criminal activity during a certification audit, by the illegal nature of the issue the auditor se well-being and safety should be assured.

The process sampling activities used within such certification audits are constrained by the time available, planned frequency of verification activities, volume of data to be assessed, any planned or unplanned sampling bias, and the potential for deviation from the scope of the audit (Manning, 2013). Martz (2010) suggested that "evaluation myopia", the inability of the auditor to identify side effects or side impacts due to the rigid application and non-reflective use of a certification standard or a "checklist" may also occur. This can lead to an auditor only verifying the effectiveness of the control of food safety and food management standards criteria that have been defined in the certification or audit standard or are already "known". As already discussed the checklist does not implicitly address food standards, but instead focuses on food safety and food quality, then the potential for EMA, or its actual practice, might go unverified. The Elliott Report (HM Government, 2013) recommends that third party accreditation bodies should collect and analyse food surveillance 
samples as this would act as an additional deterrent to food businesses knowingly trading in fraudulent food. This has potential to address known types of fraudulent activity; however emerging hazards or "unknown unknowns" are outside the scope of a biannual or triennial updating of a certification scheme and associated product sampling so emerging issues cannot be addressed by this approach and still pose an issue unless regular revision activities take place within the certification body and by the "standard owner" e.g. the British Retail Consortium. Therefore this approach has limitations in addressing EMA and food criminality.

\section{Role of food policy in minimising food adulteration}

Food fraud that results in public health risk is often unknown until it is too late and the product is already in circulation and has potentially been ingested. Even then the illegal activity may only be identified by chance or as a result of a horizon scanning activity rather than from a formal riskbased approach or an annual third party audit. Predicting types of adulterants and ways of manipulation can be carried out using the Rational Choice Theory (assuming rational choices by the fraudsters which may not be the case) or indeed in terms of food bioterrorism where irrational behaviour may well underpin the behaviours that occur. The CARVER + Shock tool is a food defensive tool to assess how vulnerable a food system or infrastructure is to an attack (Manning and Soon, 2013). It allows food regulators to think like the attackers. This methodology has led to the development of Vulnerability Assessment Software (VAS) tool (FDA, 2013a). This has been designed to be a prioritization tool that can be used to assess the vulnerabilities within a system or infrastructure in the food industry in order to build an effective food defense system. Carver + Shock and VAS tools focused on predicting attacks, but are not designed to assess vulnerabilities in the food supply chain for EMA issues. The attacker(s) of a food system ultimately wants to hurt consumers, cause economic losses and/or reputation and to generate chaos. It is carried out with the goal that the attack will be revealed within a period of time. Since food fraud or EMAs are carried out for economical gains, fraudsters will conceal their act in order to gain as much profit as 
possible. Similar systems can be developed to assess the likelihood of food fraud or EMA occurring in the food chain. In this case, the critical points for food adulteration are points where fraudsters have the opportunity to use/substitute/addition different ingredients (i.e. agricultural/veterinary inputs / processing stage) and different packaging/labeling (i.e. at packaging or distribution stage) (Figure 1). In future, after incorporating food fraud methodology into certification standards, supply chain assurance and product verification, it may be equally difficult to remember a national or organizational food standards control programme without there being a food fraud preventive system in place as it would be now a food safety system without the use of HACCP plans (Spink and Moyer, 2013). The following section discusses the policy initiatives in the US, and UK/EU that address food adulteration including EMA.

\section{United States}

The US Federal Food and Drugs Act 1906 was introduced to prevent the manufacture, sale, or transportation of adulterated or misbranded or poisonous or deleterious foods, drugs, medicines, and liquors, and for regulating traffic therein (FDA, 2013b). The Meat Inspection Act (1906) was passed on the same day. This was superseded by the Federal Food, Drug, and Cosmetic (FDC) Act of 1938, and then the Public Health Security and Bioterrorism Preparedness and Response Act of 2002 with Section 302 specifically addressing protection against the adulteration of food (FDA, 2013c). Section 302 gives high priority to increasing the number of inspections of food offered for import with the greatest priority given to inspections to detect intentional adulteration. The US passed the Food Safety Modernization Act (FSMA) in January 2011. This is considered a landmark law that shifts the food safety focus from reactive to preventive thus more in line with the European approach. The FSMA addresses imported food safety under the Foreign Supplier Verification section where importers have the responsibility to verify inspection, testing and trace back systems (FDA 2013d). In the US, there are three main federal agencies that have primary responsibility for the safety of imported foods (Zach et al. 2012): 
- Bureau of Customs and Border Protection (CBP);

- USDA Food Safety Inspection Service (USDA/FSIS); and

- US Food and Drug Administration (FDA)

Under the FSMA, these three agencies (CBP, FSIS, FDA) enforce, collaborate and communicate between each other to reduce the risk of unsafe food.

\section{United Kingdom / European Union}

The UK introduced the Preventing the Adulteration of Articles of Food or Drink Act into law in 1860 and it was revised by the Adulteration of Food and Drugs Act 1872. This led to the formation of the Society of Public Analysts in 1874. The advent of the "due diligence" defense in the UK Food Safety Act 1990 meant that organizations had to then prove that they were proactive in ensuring the food they had been supplied was not injurious to health and was of the nature, substance and quality demanded by the purchaser. The legislation differentiated between food that was sold at retail stages that was "branded" or "own-label" i.e. sold under the retailers"e brand. Under the Food Safety Act 1990, any supplier of a branded product was responsible for the safety of that product, and enforcement could be taken against a wholesaler or retailer even if the offense was caused by other parties in the food chain (Lee, 2006). Whilst major multiple food retailers in the UK gained commercial advantage from increased sales of own-branded food products, it also exposed them to greater risks in the event of product failure. This encouraged retailers to institute stringent private assurance programmes with their suppliers (Fearne, 1998). This so called "field to fork" or "plough to plate" approach led to systems that were complex and very costly elements of the procurement of own-label products (Henson and Northern, 1998). As a means to mitigate this cost the food retailers initiated the development of third-party inspection and then third-party certification of their suppliers, as previously described in this paper whilst still seeking to maintain an acceptable level of risk with regard to product failure in terms of their own verification activities. 
European legislation (EC Regulation 178/2002) lays down the general principles and requirements of food law, the establishment of the European Food Safety Authority (EFSA) and it also defined procedures in matters of food safety. Article 8 addresses protection of consumers' interests in the European Union (EU) and states that food law shall aim at the protection of the interests of consumers and "shall provide a basis for consumers to make informed choices in relation to the foods they consume. It shall aim at the prevention of:

(a) fraudulent or deceptive practices;

(b) the adulteration of food; and

(c) any other practices which may mislead the consumer".

The requirements of Article 8 also differentiate between food safety and food standards criteria. This led onto the development of the Rapid Alert System for Food and Feed (RASFF) in Europe for identifying non-conformance within the MS. The Emerging Risk Exchange Network (EREN) is the principal body for exchanging information on emerging risks between the EFSA, MS, the EC and also international organisations. The network consists of national experts and allows information exchange through the facilitation of access to and exchange through sharing of databases (Randles, 2012). In the UK, the intelligence from the EREN network along with data from other sources feeds into the Food Fraud Database. The data from these sources will feed into the predictive element of the systems to address EMA and food crime on a global scale, however localised EMA and food crime also needs to be considered.

\section{Developing a conceptual framework}

The conceptual framework developed as a result of this research focuses on the process of predicting, reacting and detecting economically and criminally food adulteration and builds on the work of Ribble et al. (2013) (Figure 1). At the beginning of the chain, integrity can be assured at a specific point that is before any potential attacks or substitution is possible. As the food and/or feed is utilized, produced or processed within the supply chain, or supply network, opportunities arise for 
criminals and fraudsters to add/extract/substitute/mix/dilute the material with any substance that diminishes the integrity of such food. If EMAs were to take place at any point in the food chain, the food safety and food standards system relies solely upon the reaction / detection protocols and system that have been developed. These protocols and systems may work through a process of either passive or reactive surveillance activity. The use of supply chain intelligence needs to feed into these protocols to enhance their ability to react to potential attacks or to suspicion of EMA activity. Inspection protocols and product testing programmes are developed through a risk assessment process that might only be undertaken on an annual basis and such attacks may occur much more frequently. Further product testing has been focused historically on looking for specific "known" adulterants rather than determining the degree of product integrity. However as shown in Tables 2 and 3 fingerprinting technologies are developing and their more widespread use will assist to determine product integrity. Furthermore compliance, or not, with an integrity fingerprint does not require the test to determine the actual agent used in an EMA, just that an attack has taken place and that product integrity is now uncertain. If the food adulterant manages to bypass passive mechanisms of control, the adulterated food may ultimately cause acute or chronic illness in the population or the concern over such illness cause substantial economic loss.

Concurrent risk assessment studies on economic and social factors (e.g. pressure on food prices, animal disease outbreaks, or weather events causing crop loss) together with associated predictive modeling can be utilized to predict the potential for EMA and wider food crime. Policy measures introduced require the implementation of both predictive measures and also reaction and detection methods.

\section{Take in Figure 1}

Prediction of food adulteration rests upon the appropriate analysis of intelligence through the use of predictive tools and expert knowledge. Cassidy and Buede (2009) argued that expert accuracy is, in general, no better than that achieved by chance as increased experience is often accompanied by an unjustified increase in self-confidence. They assert that there is a strong general tendency for 
overconfidence when making predictions or statements of uncertainty, i.e. the predicted probability of an event is often not calibrated with its actual likelihood of occurring based on the work of Koehler et al. (2002), Yates et al. (1998) and Litchtenstein et al. (1982). Whilst this research was looking at the ability to determine risk associated with issues such as whether it could be suggested that this factor of expert accuracy is the same when qualitatively, or semi-qualitatively determining the risk associated with food adulteration or food crime too. Koehler et al., (2002) identified five areas for calibrating expert judgment:

- Overprediction: always assigning probabilities that are high;

- Underprediction: Always assigning probabilities that are low

- Overextremity: overestimating high probabilities and underestimating low probabilities

- Underextremity: Underestimating high probabilities and overestimating low probabilities and

- Overconfidence: being either overprediction or overextremity.

Angner (2006) in his work on overconfidence with economic experts highlighted that overconfidence increases with difficulty i.e. the more unknown a factor the more likely that overconfidence occurs. Whilst this may in part lie within the requirements of the precautionary principle associated with European food policy there is potential concern when considering EMA and food fraud that the expert assessment will be incorrect and then the resultant decision on the actions to take. Anger (2006) further argues that in their role as "experts", individuals may not receive adequate outcome feedback i.e. they will never know what would have happened in the absence of the implementation of their recommendations. It is equally important that the actual outcomes of the implementation of their advice is fed back into the expert analysis of the future. However it is important in this case in hindsight not to exaggerate the predictability of past events. Therefore, how can the bias of overconfidence be mitigated in frameworks such as Figure 1 ? Angner (2006) suggests: 
- Accepting that overconfidence will occur and if possible eliminating it over time by requiring experts to give arguments against their view and the reasons why they may be wrong and providing feedback on decisions that is frequent, prompt, and unambiguous;

- Require clarity in predictions and decisions so that they are not ambiguous and ensure predictions are on the public record; and

- Minimise interpersonal differences between experts.

In predicting EMA and food crime it is important to consider the contributing factors that influence the incidence of food crime such as the motive, ability to detect the adulterant (known/unknown) the ability of the fraudster/criminal to cheat existing analytical tests, the strength of regulatory and market controls at the point of adulteration/criminal activity and at the point of consumption, the economic or supply chain factors (pressure on food prices, factors impacting on balance between supply and demand) and the complexity of supply chain and the influence of cross-border activity.

Databases and risk assessment measures as well as predictive modelling and intelligence gathering will be undertaken in order to identify the potential for EMA and food crime. Reaction and detection measures will depend on the agents of adulteration/substitution and the type of food fraud. Table 1 identified seven different types of food fraud and the reaction/detection measures will vary.

Activities to predict the potential for adulteration or even bioterrorism have an inbuilt weakness because the quantification of risk is usually based on historical data that may, or may not be available or may/may not reflect the actual risk now at any given time in the future. Food fraud that results in public health risk is often unknown until it is too late and may only be identified by chance rather than from a formal risk-based approach; however there is a need to develop such predictive models for the future.

Historically, analytical screening techniques were used to identify EMA, and wider food crime, but this is only of value if the nature of the adulterant is known. There are evolving food forensics 
621 techniques that will be able to determine food integrity through techniques such as isotope analysis

622 or spectroscopy that do not require the contaminant to be known rather that food integrity or purity,

623 to the level of detection, cannot be shown. This investigative framework is valuable as a means to 624 fight food fraud/EMA. However, these tests are costly and will by and large, in the short term 625 anyway, be used as a tool of verification and not as a form of analysis for routine batch release. 626 Therefore they cannot be used as either a preventative control, or an on-line, real-time monitoring 627 activity within an established quality plan.

628 The objective of this study was to explore the current strategies available to monitor and detect the 629 EMA and their relative strengths and weaknesses and recommend new approaches and policies to 630 strengthen future capabilities to counter adulteration in a globalized food environment. The 631 conceptual framework developed in this research focused on the process of predicting, reacting and 632 detecting economically and criminally food adulteration, with specific emphasis on calibrating the 633 confidence of experts as this underpins the horizon scanning, risk assessment and predictive 634 processes as well as informing the requirements to ensure effective reactions and detections are 635 undertaken. 
638

639

640

641

642

643

644

645

646

647

648

649

650

651

652

653

654

655

656

657

658

659

660

661

662

663

664

665

666

667

668

669

670

671

672

673

674

675

676

677

678

679

680

681

682

683

684

685

686

687

Accum, F. (1820), A treatise on adulterations of food and culinary poisons. London: Longman, $1820 . \quad$ Available at: http://ia600300.us.archive.org/18/items/treatiseonadulte00accurich/treatiseonadulte00accurich.pdf [Date accessed 17.10.13]

Brown, C. A. and Brown, S. A. (2010). Food and pharmaceuticals: Lessons learned from global contaminations with melamine/cyanuric acid and diethylene glycol. Veterinary Pathology 47(1): $45-52$.

Archak, S., Lakshminarayanareddy, V., and Nagaraju, J. (2007) High-throughput multiplex microsatellite marker assay for detection and quantification of adulteration in Basmati rice (Oryzasativa).Electrophoresis 28, 2396-2405

Bhalla, V. Grimm, P.C., Chertow, G.M., and Pao AC. (2009), Melamine nephrotoxicity: an emerging epidemic in an era of globalization. Kidney Int.75:774-779.

Blyth, A,W. (1896), Foods: Their Composition and Analysis, 1896, Edition 4, Charles Griffin and Company Limited, London.

BRC (2005), Code of Practice on Basmati Rice. In Consultation with the Local Authorities Coordinators of Regulatory Services (LACORS) and the Association of Public Analysts (APA). July 2005. Available at: http://www.brc.org.uk/Downloads/Basmati Code.pdf]Date accessed $10 / 05 / 2013]$

CAC (Codex Alimentarius Commission) (2011), "The 20th Edition of the Procedural Manual of Codex Alimentarius Commission”, Available

http://www.codexalimentarius.net/web/procedural_manual.jsp[Date accessed 08/04/12]

CAC (Codex Alimentarius Commission) (2007), "Principles and Guidelines for the Conduct of Microbiological Risk Management (MRM)", (CAC/GL 63-2007)", Food hygiene basic texts, available at: www.codexalimentarius.net/download/standards/10741/cxg_063e.pdf]Date accessed 17.10.13]

Casale, M., Oliveri, P. and Armanino, C. (2010). NIR and UV-vis spectroscopy, artificial nose and tongue: comparison of four fingerprinting techniques for the characterisation of Italian red wines. AnalyticaChimicaActa668: 143-148.

Cawthorn, D., Steinman, H.A., and Hoffman, L.C., (2013). A high incidence of species substitution and mislabelling detected in meat products sold in South Africa, Food Control, 32 (2): 440-449

Charlton, A. (2010). Addressing Emerging Issues of Food Adulteration and Authenticity.Fera/JIFSAN symposium, 16-18 June 2010.York, UK

Chirnside, R.C, and Hamence, J.H. (1974), The Practising Chemists, A History of the Society for Analytical Chemistry 1874-1974, 1974, The Society for Analytical Chemistry.

Clare, P and Clare, M. (2012), The Life and Times of Alfred Henry Allen, Sheffield's First Public Analyst, Journal of the Association of Public Analysts (Online) 40: 39-59 Available at: http://www.apajournal.org.uk/2012_0039-0059.pdf [Date accessed 17.10.13] 
Coghlan, A (2011) China makes 96 arrests over toxic milk scandal New Scientist 13 January. Available at: http://www.newscientist.com/blogs/shortsharpscience/2011/01/china-makes-96-arrests-over-to.html [Accessed 17/04/2013]

Cohen, A. (1997) Sturgeon poaching and black market caviar: a case study. Environmental Biology of Fishes 48: 423-426.
Collins
Dictionary
(2013)
Available

at http://www.collinsdictionary.com/dictionary/english/wholesome [Date accessed 17.10.13]

Dabbine, F., Gay, P. and Tortia, C. (In Press). Traceability issues in food supply chain management: A review. Biosystems Engineering.

Defra (2013) The Defra website https://www.gov.uk/food-standards-labelling-durability-andcomposition [Date accessed 17.10.13]

D"Amico, P., Armani, A., Castigliego, L., Sheng, G., Gianfaldoni, D. and Guidi, A. (2014). Seafood traceability issues in Chinese food business activities in the light of the European provisions. Food Control 35(1): 7-13.

Di Stefano, V., Avellone, G., Bongiorno, D., Cunsolo, V., Muccilli, V., Sforza, S., Dossena, A., Drahos, L. and Vekey, K. (2012).Applications of liquid chromatography - mass spectrometry for food analysis.Journal of Chromatography A 1259: 74-85.

Du, Z. and Sun, S. (2007).Determination of SUDAN Red I-IV in duck egg yolk using ultra performance liquid chromatography-tandem mass.Chinese Journal of Chromatography 25(5): 705710.

EC/178/2002 laying down the general principles and requirements of food safety law, establishing the European Food Standards Agency and laying down procedures in matters of food safety OJ L/31 1.2.2002 pp. $001-024$.

EC (2013).Commission publishes European test results on horse DNA and Phenylbutazone: no food safety issues but tougher penalties to apply in the future to fraudulent labelling Available at: http://europa.eu/rapid/press-release IP-13-331_en.htm [Date accessed 18.10.13]

Everstine, K., Spink, J., and Kennedy, S, (2013). Economically Motivated Adulteration (EMA) of Food: Common Characteristics of EMA Incidents. Journal of Food Protection, 4: 560-735

Fearne, A. (1998). The evolution of partnerships in the meat supply chain: insights from the British beef industry. Supply Chain Management: An International Journal 3(4): 214-231.

FDA (2013a) The Federal Food and Drugs Act (1906) Available at: http://www.fda.gov/regulatoryinformation/legislation/ucm148690.htm [Date accessed 17.10.13]

FDA (2013b) Public Health Security and Bioterrorism Preparedness and Response Act of 2002 (PL107-188) Available at: http://www.fda.gov/ohrms/dockets/dailys/03/jul03/070303/02n0277_emc-000029-04.htm [Date accessed 17.10.13]

FDA (2013c) Vulnerability Assessment Tool Available at: http://www.fda.gov/Food/FoodDefense/ToolsEducationalMaterials/ucm295900.htm [Date accessed 18.10.13] 
FSA (2013a).FSA issues statement following Ministry of Justice announcement about non Halal meat. Available at: http://www.food.gov.uk/news-updates/news/2013/feb/m-o-j\#.UXwOkLWG2So [Date accessed 20.10.13]

FSAAI (2011) National survey in India of adulteration in liquid milk. Available at: http://www.fssai.gov.in/Portals/0/Pdf/sample_analysed(02-01-2012).pdf[Accessed on 23/04/2013]

Galimberti, A., De Mattia, F., Losa, A., Bruni, I., Federici, S., Casiraghi, M., Martellos, S. and Labra, M. (2013). DNA barcoding as a new tool for food traceability.Food Research International50(1): 55-63.

Gossner, C.M., Schlundt, J., Embarek, P.B., Hird, S., Lo-Do-Wong, D., Beltran J.J.O., Teoh, K.N., and Tritscher, A., (2009) The Melamine Incident: Implications for International Food and Feed Safety Environ Health Perspect. 117(12): 1803-1808.

Grundy, H.H., Kelly, S.D., Charlton, A.J., Donarski, J.A., Hird, S.J., and Collins, M.J., (2012). Food Authenticity and Food Fraud Research: Achievements and Emerging Issues, Journal of the Association of Public Analysts (Online)40: 65-68

Hassall, A.H, (1855).Food and its adulterations; comprising the reports of the analytical sanitary commission of 'The Lancet' for the years 1851 to 1854. London: Longman, 1855. Available at: http://archive.org/stream/foodanditsadult01 commgoog\#page/n8/mode/2up [Date accessed 18.10.13]

He Dan (2011) Whistleblower says watchdogs relying on fines. China Daily. Available from: http://europe.chinadaily.com.cn/china/2011-04/20/content 12360918.htm [Accessed 27 November 2013]

Heaton, K., Kelly, S. D.,Hoogewerff, J and Woolfe, M. (2007) "Verifying the geographical origin of beef: The application of Multi-element Isotope and Trace Element Analysis" Food Chemistry, $107,506-515$

Henson, S., and Northen, J., 1998.Economic determinants of food safety controls in supply of retailer own-

branded products in United Kingdom Agribusiness 14(2): 113-126.

Hubert, N., Hanner, R., Holm, E. Mandrak, N. E. and Taylor, E. (2008).Identifying Canadian freshwater fishes through DNA barcodes.PLoSONE 3(6): e2490.

HM Government (2013) Elliott Review into the Integrity and Assurance of Food Supply Networks - Interim Report Available at https://www.gov.uk/government/publicationsPB 14089.

IFRTF (2011) The report of the independent Farming Regulation Task Force. Striking a balance: reducing burdens; increasing responsibility; earning recognition. A report on better regulation in farming and food businesses.Summary of Recommendations. May 2011 PB13528 Available at: https://www.gov.uk/government/uploads/system/uploads/attachment data/file/69202/pb13528farm-reg-task-summary1.pdf [Accessed on: 09/05/2013]

Jia, C. and Jukes, D. (2013). The national food safety control system of China - A systematic review. Food Control 32(1): 236-245. 
Jia, X., Huang, J., Luan, H., Rozelle, S., and Swinnen J. (2012) China ${ }^{e c}$ S Milk Scandal, government policy and production decisions of dairy farmers: The case of Greater Beijing. Food Policy 37: $390-400$

Kelly, S.D., and Bateman A.S. (2009), Comparison of Mineral Concentrations in Commercially Grown Organic and Conventional Crops - Tomatoes (Lycopersiconesculentum) and Lettuces (Lactucasativa), Food Chemistry, 119: 738-745

Kelly, S., Heaton, K. and Hoogewerff, J. (2005).Tracing the geographical origin of food: The application of multi-element and multi-isotope analysis. Trends in Food Science \& Technology 16(12): 555-567.

Kelly, S.D. (2003), Using Stable Isotope Ratio Mass Spectrometry in Food Authentication and Traceability, Food Authenticity and Traceability, Michele Lees(Ed), Woodhead Publishing, Cambridge, UK, ISBN 0-8493-1763-0, 156-183

Kim, H.M., Fox, M.S. and Gruninger, M. (1995) 'Ontology of Quality for Enterprise Modelling' In Proceedings of WET-ICE, Los Albamitos, CA, USA, pp.105 \pm 116 , IEEE

Kitaoka, M., Wada, T., Nishio, T.AndGoto, M. (2010).Fluorogencribonuclease protection (FRIP) analysis of single nucleotide polymorphisms (SNPs) in Japanese rice (Oryzasativa L.)DNA for cultivar discrimination.Bioscience, Biotechnology and Biochemistry 74(11): 2189-2193.

Lee, G.C.-H., (2006).Private food standards and their impacts on developing countries. European Commission

DG Trade Unit G2. Available at: http://trade.ec.europa.eu/doclib/docs/2006/november/tradoc_127969.pdf [Date accessed 13/03/2013].

Li, L. (2013). Technology designed to combat fakes in the global supply chain. Business Horizons 56(2): $167-177$

Liu, X., Guo, B., Wei, Y., Shi, J and Sun, S., (2013) Stable isotope analysis of cattle tail hair: A potential tool for verifying the geographical origin of beef. Food Chemistry, Issues 1-2, 1-15 Sept $2013135-140$

Liu, S., Xie, Z., Zhang, W., Cao, X. and Pei, X. (2013). Risk assessment in Chinese food safety. Food Control 30(1): 162-167

London Borough of Tower Hamlets (2010) Food Law Enforcement Plan 2010/2011. [online] Available from: http://www.towerhamlets.gov.uk/pdf/FSA $\% 20$ Service $\% 20 \mathrm{Plan} \% 202010-11$.pdf [Date accessed 18.10.13]

Manning, L. (2013), Development of a food safety verification risk model, British Food Journal, 115(4): 575-589

Manning L., Baines R.N., and Chadd S.A. (2005), "Deliberate contamination of the food supply chain", British Food Journal, 107(4): 225-245.

Manning, L. and Soon, J. M. (2013), "Mechanisms for assessing food safety risk", British Food Journal, 115(3): 460-484 
Maralit, B. A., Aguila, R. D., Ventolero, M. F. H., Perez, S. K. L., Willette, D. A. and Santos, M. D. (2013).Detection of mislabelled commercial fishery by-products in the Philippines using DNA barcodes and its implications to food traceability and safety.Food Control 33(1): 119-125.

Martz, W. (2010), "Validating an evaluation checklist using a mixed method design", Evaluation and Program Planning, 33: 215-222. Available at: http://dx.doi.org/10.1016/j.evalprogplan.2009.10.005 [Date accessed 18.10.13].

Merck Research Laboratories (2001).The Merck index. 13 ${ }^{\text {th }}$ ed. Merck Research Laboratories, Whitehouse station: New Jersey.

Moe T. (1998). Perspectives on traceability in food manufacture.Trends in Food Science and Technology, 9: 2111-214

Moore, J.C.Spink, J., and Lipp, M. (2012).Development and application of a database of food ingredient fraud and economically motivated adulteration from 1980 to 2010.Journal of Food Science, 77(4):R118-126

Moore, J. C., DeVries, J. W., Lipp, M., Griffiths, J. C.And Abernethy, D. R. (2010). Total protein methods and their potential to reduce the risk of food protein adulteration. Comprehensive Reviews in Food Science and Food Safety 9: 330-357.

Niu, L., Mantri, N., Li, C.G., Xue, C., Wohlmuth, H and Pang, E.C. (2011).Detection of Panaxquinquefolius in Panax ginseng using 'subtracted diversity array'. J. Sci Food Agri. 91(7): 1310-5

Primrose, S., Woolfe, M. and Rollinson, S. (2010). Food forensics: methods for determining the authenticity of foodstuffs. Trends in Food Science and Technology 21(12): 582-590.

Randles, P (2012) Emerging Risks. Paper given to the $57^{\text {th }}$ Meeting of the Advisory Committee on Animal Feedstuffs on $7^{\text {th }}$ March 2012 http://www.food.gov.uk/multimedia/pdfs/committee/acaf1201.pdf [Accessed on 11.12.13]

Razmy, A. (2009). Will Chinaes new food-safety laws work? Time March 3 2009. Available at: http://www.time.com/time/world/article/0,8599,1882711,00.html[Accessed 26/04/ 2013].

Ravilious, K. (2006) Buyer beware: the rise of food fraud. NewScientist 15 November. Available at: http://www.newscientist.com/article/ [Accessed 17/04/ 2013]

Ribble, C.S., Stitt, T., Burns, T., Dawson, J., Iwasawa, S., Buntain, B., Stephen, C., Rajic, A. and Merten, C. (2013). Structured review and expert opinions on early warning and rapid alert systems applicable to food safety. Technical Report, Centre for Coastal Health and FAO.

Rock, L. (2012) The use of stable isotope techniques in egg authentication schemes: A review Trends in Food Science \& Technology 28 (2012) 62-68

Scally, G. (2013).Adulteration of food: what it doesn "t say on the tin BMJ 2013; 346:f1463

Schmidt, O., Quilter, J.M., Bahar, B., Moloney, A.P., Scrimgeour, C.M., Begley, I.S., and Monahan, F.J., (2004) Inferring the origin and dietary history of beef from C, N and S stable isotope ratio analysis. Food Chemistry 91 (2005) 545-549

Schoder, D. (2010). Melamine milk powder and infant formula sold in East Africa. Journal of Food Protection 73(9): 1709-1714. 
Sefc, K. M., Lopes, M. S., Mendonça, D., Rodrigues Dos Santos, M., Laimer Da CâmaraMacahado, M. and Da Câmara Machado, A. (2000).Identification of microsatellite loci in olive (Oleaeuropaea) and their characterization in Italian and Iberian olive trees.MolecularEcology9(8): 1171-1173.

Serge, R., Ivan.G.andKaroly, H. (2007). Classification of gilthead sea bream (Sparusaurata) from ${ }^{1} \mathrm{H}$ NMR lipid profiling combined with principal component and linear discriminant analysis. Journal of Agricultural and Food Chemistry 55: 9963-9968.

Shukla, S., Shankar, R. and Singh, S. P. (2014).Food safety regulatory model in India. Food Control 37: 401-413.

Spink, J. and Moyer, D. C. (2013).Understanding and combating food fraud.Food Technology 67(1): 30-35.

Spink, J. and Moyer, D. C. (2011).Defining the public health threat of food fraud. Journal of Food Science 76(9): R157-R163.

Sykes, J. B. (1976). The concise Oxford dictionary.University Press, Oxford.

Thomson, H. (2013) DNA tests can prevent the next horsemeat scandal. NewScientist 13 February. Available at: http://www.newscientist.com/article/mg21729043.800-dna-tests-can-prevent-the-nexthorsemeat-scandal.html?full=true [Accessed 16/04/2013]

US FDA (2008). FDA advises consumers to avoid toothpast from China containing harmful chemical. $\quad 2007 . \quad$ June Available from: http://www.fda.gov/NewsEvents/Newsroom/PressAnnouncements/2007/ucm108927.htm [Accessed 2 December 2013]

US FDA (2013).Food Safety Modernization Act (FSMA). U.S. Food and Drug Administration. Available http://www.fda.gov/food/guidanceregulation/fsma/ucm247548.htm\#TITLE_III[Accessed at: December 2013]

US Pharmacopeia (2012). Food Chemicals Codex . Available at http://www.usp.org/foodingredients/food-chemicals-codex. [Accessed 7/05/2013]

Valeria, T., Caterina, M. and Antonio, G. (2005).DNA-based methods for identification and quantification of small grain cereal mixtures and fingerprinting of varieties. Journal of Cereal Science 41: 213-220.

Vinci, G., Preti, R., Tieri, A., and Vieri, S. (2012), Authenticity and quality of animal origin food investigated by stable isotope ratio analysis. Journal of the Science of Food and Agriculture 93 (3): 439-448

Warner, K., Timme, W., and Lowell, B. (2012).Widespread Seafood Fraud Found in New York City Oceana. December 2012 Available at:

http://209.183.226.238/sites/default/files/reports/Oceana_NYC_Seafood_Fraud_Report_FINAL.pdf [Date accessed 20.10.13]

WHO (2008) Melamine-contaminated powdered infant formula in China. Available at: http://www.who.int/csr/don/2008_09_19/en/[Accessed 26/03/ 2013]. 
WHO (1997) "Food Safety and Globalization of Trade in Food, a challenge to the public health sector".WHO/FSF/FOS/97.8 Rev. 1, WHO, Geneva

Woolfe, M. and Primrose, S. (2004). Food forensics: using DNA technology to combat misdescription and fraud. Trends in Biotechnology 22(5): 222-226.

Xiaojing, L (2011) The cause and effect analysis of the melamine incident in China. Asian Journal of Agricultural Research 5 (3): 176-185

Xinhua News (2010). A new incident of formula contaminated with melamine found in Qinghai Province. Available from http://news.xinhuanet.com/food/2010-07/09/c 12314950.htm [Accessed 27 November 2013]

Xiu, C. and Klein, K. K. (2010). Melamine in milk products in China: Examining the factors that led to deliberate use of the contaminant. Food Policy 35: 463-470.

Zach, L., Doyle, M. E., Bier, V. and Czuprynski, C. (2012). Systems and governance in food import safety: A U.S. perspective. Food Control 27 (1): 153-162.

Zhang, J., Zhang, X., Dediu, L. and Victor, C. (2011). Review of the current application of fingerprinting allowing detection of food adulteration and fraud in China.Food Control 22(8): 11261135.

Angner, E., (2006) Economists as experts: Overconfidence in theory and practice. Journal of Economic Methodology, 13 (1) 1-24

Koehler, D.J., Brenner, L. and Griffin, D. (2002), “The calibration of expert judgment: heuristics and biases beyond the laboratory", in Gilovich, T., Griffin, D.W. and Kahneman, D. (Eds), Heuristics and Biases: The Psychology of Intuitive Judgment, Cambridge University Press, Cambridge.

Lichtenstein, S., Fischhoff, B. and Phillips, L.D. (1982), "Calibration of probabilities: the state of the art to 1980", in Kahneman, D., Slovic, P. and Tversky, A. (Eds), Judgment under Uncertainty: Heuristics and Biases, Cambridge University Press, Cambridge.

Yates, J.F., Lee, J.W., Shinotsuka, H., Patalano, A.L. and Sieck, W.R. (1998), “Cross-cultural variations in probability judgment accuracy: beyond general knowledge overconfidence", Organizational Behavior and Human Decision Processes, 74 (2) 89-117.

Cassidy, M.F., and Buede, D. (2009), Does the accuracy of expert judgment comply with common sense: caveat emptorManagement Decision 47 (3), 454-469 
Table 1: Types of food fraud (Adapted from Spink and Moyer, 2011)

\begin{tabular}{|l|l|}
\hline \multicolumn{1}{|c|}{ Type } & \multicolumn{1}{c|}{ Definition } \\
\hline Adulteration & A component of the finished product is fraudulent \\
\hline Counterfeit & All aspects of the fraudulent product and packaging are fully replicated \\
\hline Diversion & The sale or distribution of legitimate products outside of intended markets \\
\hline Over-run & Legitimate product is made in excess of production agreements \\
\hline Simulation & $\begin{array}{l}\text { Illegitimate product is designed to look like but does not exactly copy the legitimate } \\
\text { product }\end{array}$ \\
\hline Tampering & Legitimate product and packaging are used in a fraudulent way \\
\hline Theft & Legitimate product is stolen and passed off as legitimately procured \\
\hline
\end{tabular}

Table 2: Classification of fingerprinting technologies (Adapted from Zhang et al.2011)

\begin{tabular}{|c|c|c|c|c|}
\hline \multirow[t]{2}{*}{ Methods } & \multicolumn{2}{|c|}{ Electrophoresis fingerprinting } & \multirow{2}{*}{$\begin{array}{c}\text { Spectral } \\
\text { fingerprinting }\end{array}$} & \multirow{2}{*}{$\begin{array}{c}\text { Chromatographic } \\
\text { fingerprinting }\end{array}$} \\
\hline & $\begin{array}{c}\text { Biochemical } \\
\text { fingerprinting }\end{array}$ & $\begin{array}{c}\text { Protein } \\
\text { electrophoresis, } \\
\text { isoenzyme } \\
\text { electrophoresis }\end{array}$ & & \\
\hline & $\begin{array}{l}\text { DNA } \\
\text { fingerprinting }\end{array}$ & $\begin{array}{l}\text { Restriction fragment } \\
\text { length polymorphism } \\
\text { (RFLP) } \\
\text { Random Amplified } \\
\text { Polymorphic DNA } \\
\text { (RAPD) } \\
\text { Amplified Fragment } \\
\text { Length } \\
\text { Polymorphism } \\
\text { (AFLP) } \\
\text { Pulsed-field gel } \\
\text { electrophoresis } \\
\text { (PFGE) }\end{array}$ & $\begin{array}{l}\text { Nuclear Magnetic } \\
\text { Resonance (NMR), } \\
\text { Infrared (IR) } \\
\text { Ultraviolet and } \\
\text { visible } \\
\text { spectroscopy (UV) } \\
\text { Mass spectrometry } \\
\text { (MS) }\end{array}$ & $\begin{array}{l}\text { Gas chromatography } \\
\text { (GC) } \\
\text { High performance liquid } \\
\text { chromatography } \\
\text { (HPLC) }\end{array}$ \\
\hline
\end{tabular}


Table 3: Application fields of fingerprinting in food detection (adapted from Charlton, 2010;

Niuet al., 2011; Sefcet al. 2000; Woolfe and Primrose 2004; Zhang et al. 2011)

\begin{tabular}{|l|l|l|l|}
\hline Application domain & \multicolumn{1}{|c|}{ Products } & Detection indicators & Detection Technology \\
\hline Origin & $\begin{array}{l}\text { Tea, beer, mutton, } \\
\text { olive oil, wine }\end{array}$ & $\begin{array}{l}\text { Microelements, water, } \\
\text { lipid, protein, } \\
\text { carbohydrate, aromatic } \\
\text { compound, isotope } \\
\text { indicators }\end{array}$ & NMR, IR, PCR \\
\hline Material/species & $\begin{array}{l}\text { Birdes nest, aquatic } \\
\text { product, poultry, } \\
\text { vegetables, Basmati } \\
\text { rice, Genseng }\end{array}$ & Protein, DNA & $\begin{array}{l}\text { SDS-PAGE, } \\
\text { Isoenzyme } \\
\text { electrophoresis, RFLP, } \\
\text { RAPD, AFLP, small } \\
\text { sequence length } \\
\text { polymorphism } \\
\text { (SSLPs) }\end{array}$ \\
\hline Component & $\begin{array}{l}\text { Milk, fruit, edible oil, } \\
\text { tea, beef, ham, health } \\
\text { products }\end{array}$ & $\begin{array}{l}\text { Protein, lipid, lecithin, } \\
\text { vitamins, sugars, } \\
\text { organic acid, }\end{array}$ & $\begin{array}{l}\text { SDS-PAGE, NMR, IR, } \\
\text { UV, MS }\end{array}$ \\
\hline Additive & $\begin{array}{l}\text { Meat, milk, juice, } \\
\text { processed food, } \\
\text { carbonated beverages, } \\
\text { ice-cream }\end{array}$ & $\begin{array}{l}\text { Nitrite, sufan, } \\
\text { melamine, clebuterol } \\
\text { hydrochloride, } \\
\text { colorants, antiseptic }\end{array}$ & UV, GC, LC, MS \\
\hline $\begin{array}{l}\text { Objectionable } \\
\text { constituent } \\
\text { processing }\end{array}$ & $\begin{array}{l}\text { Fried starch products, } \\
\text { margarine, barbeque }\end{array}$ & $\begin{array}{l}\text { Acrylamide, trans-fatty } \\
\text { acids, benzopyrene }\end{array}$ & UV, GC, LC, MS \\
\hline
\end{tabular}




\section{Predicting EMA and food crime}

\section{Contributing factors}

Motive (rational/irrational - terrorism etc)

Ability to detect adulterant (known/unknown)

Ability to cheat existing analytical tests

Strength of regulatory and market controls at point of

adulteration/criminal activity and at point of consumption

Economic or supply chain factors (pressure on food prices,

factors impacting on balance between supply and demand)

Complexity of supply chain and influence of cross-border activity

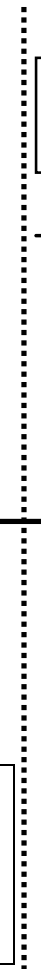

RASFF / VAS tool / CNCFSRA

Horizon scanning activities;

Multidisciplinary expert panels or think tanks and degree of

accuracy of expert knowledge - mitigation of overconfidence

\section{Predictive modeling/intelligence gathering such as the FFD;}

Outcome feedback from the react/detection phase

Media and social network surveillance;

Criminal and industry intelligence

Monitoring of unusual over-the-counter drug sales or chemical

sales;

Unusual spike in sick animals

Economic trends

\section{React / Detect}

Earliest time before food and feed is adulterated

i.e. when integrity can be assured

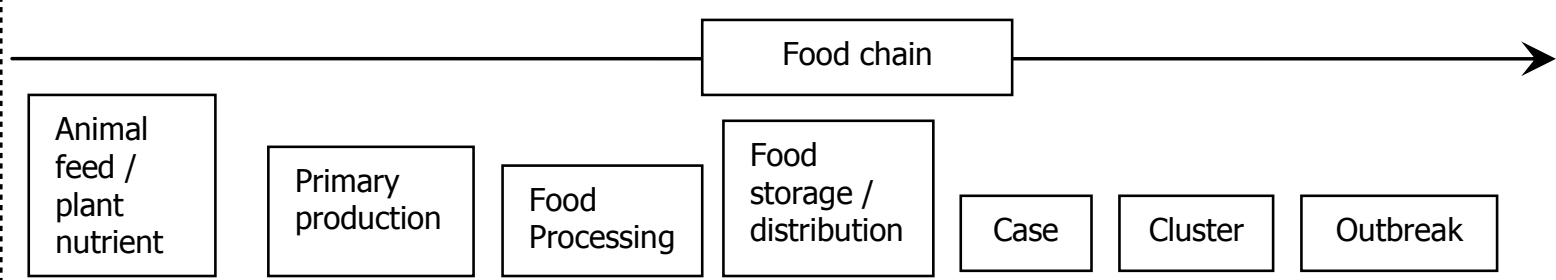

Processing

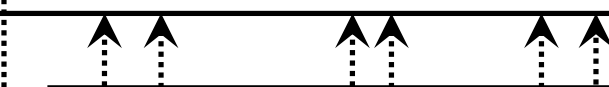

Passive laboratory surveillance of animal health and wellbeing (agents contained within adulterated feed)

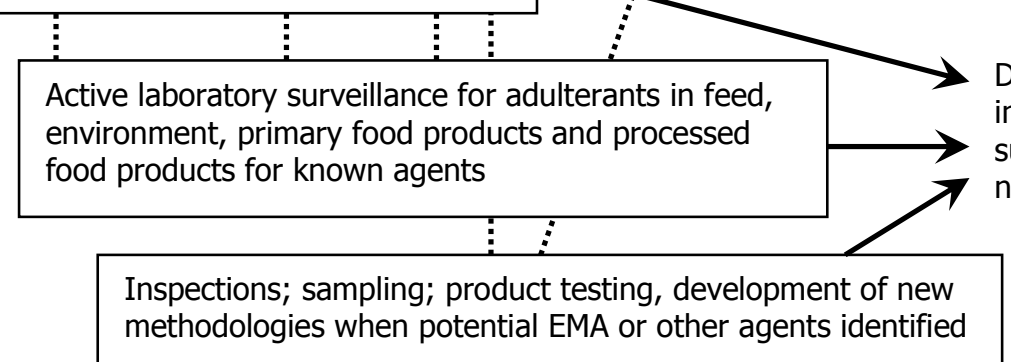

Product recall; fines; licenses' revoked; jail terms; company temporary / permanent closure; death penalty (e.g. China's melamine case)

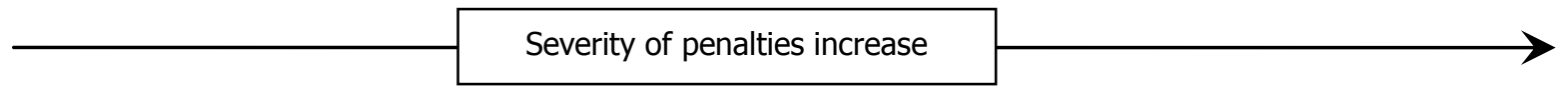

Figure 1. Predictive and reactive systems for food adulteration - role of food policy and risk assessment centres (adapted from Ribble et al. 2013) (Note: RASFF: Rapid Alert System for Food and Feed; VAS - Vulnerability Assessment Software; FFD - Food Fraud Database; CNCFSRA: China National Center for Food Safety 